\title{
Article
}

\section{Effect of antipsychotic drugs and orthostatic hypotension on the risk of falling in schizophrenic patients}

\author{
Ferinauli Ferinauli, ${ }^{1}$ Sari Narulita, ${ }^{1}$ Yoanita Hijriyati ${ }^{2}$ \\ ${ }^{1}$ Mental Health Nursing Department, Binawan University, Jakarta; ${ }^{2}$ Basic Nursing Department, Binawan \\ University, Jakarta, Indonesia
}

\begin{abstract}
Background: Background: Management of schizophrenia using psychopharmaceuticals requires a long-term treatment. The use of antipsychotic drugs can cause the occurrence of orthostatic hypotension, which leads to the risk of falling in patients. The aim of this study is to determine the effect of the use of antipsychotic drugs and orthostatic hypotension on the risk of falling in schizophrenic patients.

Design and Methods: This study used a descriptive design with 53 respondents. Data were analyzed using the contingency coefficient correlation and Spearman Rank test methods.

Results: The results of the first study showed no positive effect between the use of antipsychotics on orthostatic hypotension in schizophrenic patients. In addition, a contingency coefficient correlation (C) of 0.199 and $p$-value of 0.335 ( $p>0.05$ ) was obtained. The results of the second study showed that there was a significant positive effect between orthostatic hypotension on the risk of falling in schizophrenic patients with a value of $r=0.483$ and a $p$ value of 0.000 (p0.001).

Conclusion: It was suggested that the development of this study's result is needed for further research in dealing with the incidence of orthostatic hypotension in order to prevent or reduce the risk of falling in schizophrenic patients.
\end{abstract}

\section{Introduction}

Schizophrenia is a persistent neurobiological disorder, and a clinical syndrome that causes damage to the quality of life of individuals, families and communities, resulting in divisions of thoughts, emotions and behavior. ${ }^{1,2}$ Schizophrenia disorder is characterized by positive and negative symptoms, positive symptoms such as chaotic speech, delusions, hallucinations, cognitive impairment and negative perception of symptoms such as avolition (decreased interest and drive), reduced desire to speak and poor content of speech, flat affect and disrupted relationships personal. ${ }^{3}$ Furthermore, and symptoms of both depressive and mood disorders..$^{3,4}$

According to the World Health Organization, a survey that has been conducted in several countries globally showed an annual incidence of schizophrenia between 0.1-0.4 per 1000 population. 5 This high incidence occurred in social groups, especially ethnic minorities in Western Europe, such as the Afro-Caribbean community in Britain and immigrants from Suriname in the Netherlands. ${ }^{6}$ The prevalence rate from Mental Health in Southeast Asia was found in 2018, to be around 47.5 million people with depression, bipolar disorder, schizophrenia and dementia. ${ }^{6}$ Based on the data from Royal College Psychiatrists, states that patients with mental disorders have a three times greater risk of falling than patients without mental disorders. ${ }^{7}$ In London, the falls rate for mental health units ranged between 7.7 to 48 per 1000 OBDs which is higher than the fall rate for community hospitals (4.5 to 12 falls per 1000 OBDs). ${ }^{7}$ Based on the data from Basic Health Research, Research and Development of the Department of Health, schizophrenia in Indonesia is a mental disorder with an increasing prevalence from the previous year, with a total of 7 per 1000 population. ${ }^{8}$ The highest prevalence rates were found in the Bali region with about 11.0 per 1000 population, and 7.0 per 1000 population in Bangka Belitung to North Sulawesi and Jakarta Province, Indonesia. Furthermore, the lowest prevalence was found in the Riau Islands with 3.0 per 1000 population. ${ }^{8}$ Management of schizophrenia requires a long-term treatment, and an example is the use of antipsychotic drugs to relieve florid psychotic symptoms. ${ }^{9-11}$ However, antipsychotics causes side effects, ${ }^{12}$ such as orthostatic hypotension which is a sudden decrease in blood pressure due to a change in position from laying to sitting or standing. ${ }^{13}$ Furthermore, head tilt at least 60 degree on an inclined to table. ${ }^{14}$ It could also be due to the effect of single or the combination of antipsychotic drugs. ${ }^{9}$ Orthostatic hypotension that occurs as a result of the effects of antipsychotic treatment requires nurses attention, because it is a contributing factor for the occurrence of unwanted events, such as the risk of falling in patients. Therefore, the purpose of this study is to be able to develop and apply independent actions in implemented nursing interventions in order to prevent and reduce the risk of injury or falls.

\section{Design and Methods}

This study used a descriptive correlation research design with

Significance for public health

Nurses should know how to measure blood pressure in order to determine the incidence of orthostatic hypotension. Nurses have an important role to play in preventing the risk of falling in patients. This is used as an indicator in achieving the quality of patient safety and in determining the quality of services in the hospital. This study describes the effect of the use of antipsychotic drugs and orthostatic hypotension on the risk of falls in schizophrenic patients in Dr. H. Marzoeki Mahdi Hospital Bogor. 
a correlation study approach. The criteria used in selecting the respondents (inclusion) were schizophrenic patients that were being hospitalized, not being treated in a physical problem ward, not experiencing anxiety outbreak, and using antipsychotic drugs with a minimum period of 7 days. The criteria for respondents that could not be used (exclusion) were schizophrenic outpatients at the psychiatric clinic of the hospital. Furthermore, the simple random sampling technique was used with a total of 53 respondents. The research site were 5 psychiatric inpatient rooms in a hospital in Bogor City, West Java, Indonesia. The ethics agreement includes filling out an agreement form (informed consent), giving freedom of choice (autonomy), respecting the privacy and confidentiality of research subjects (respect for privacy and confidentiality), and justice and inclusiveness (respect for justice and inclusiveness).

The secondary data collection methods used (observations) include observation sheets which involves the use of antipsychotic drugs, the results of blood pressure measurements in the morning when waking up or before doing activities and after changing positions or getting out of bed. Furthermore, it includes the fall risk on the Edmonson scale used in the hospital. The instruments used include demographic data, spreadsheets on antipsychotic use, orthostatic hypotension score sheets, and Edmonson scale fallout questionnaires. Research approval was obtained from the Health Ethics Committee of the Dr. H. Marzoeki Mahdi Hospital Bogor in October 2019 (PP.08.02/258/2019) and of the Binawan University, Jakarta in November 2019 (08/EP/KE/UBINAWAN/X/2019).

The data analysis used include univariate statistics (use of a single typical antipsychotic, single atypical and combination, orthostatic hypotension value, fall risk assessment with Edmonson scale) and bivariate statistics (this includes the contingency coefficient correlation test (C) and spearman rank) in SPSS 24 to determine the effect of antipsychotic drugs and orthostatic hypotension on the risk of falling in schizophrenic patients in the hospital.

\section{Results and Discussions}

Table 1 illustrates the frequency on the use of antipsychotic drugs in schizophrenic patients that were being hospitalized in the hospital. Furthermore, about $75.47 \%$ patients used a combination type of antipsychotic drugs, $18.87 \%$ used an atypical type of antipsychotic drug and 5.66\% used a typical type of antipsychotic drug. In addition to this, $9.43 \%$ patients experienced orthostatic hypotension, while the remaining $90.57 \%$ did not experience orthostatic hypotension (Table 2). Table 3 shows that $100 \%$ of schizophrenic patients had moderate scores (51 90) of the risk of falls. The result of the bivariate analysis is shown in Tables 4 and 5 as follows: Based on Table 4, the results of statistical tests using the contingency coefficient correlation analysis (C) produced a value of 0.199 with a $p$-value of 0.335 (alpha value $>0.05$ ). This means that there was no significant positive effect between the use of antipsychotics on orthostatic hypotension for schizophrenia patients. Furthermore, the results showed that out of $100 \%$ respondents that had a combination type of antipsychotics drugs, 3 (7.5\%) of them experienced orthostatic hypotension, while 37 $(92.5 \%)$ experienced no orthostatic hypotension. Out of the 10 respondents (100\%) using atypical antipsychotics, 1 (10.0\%) experienced orthostatic hypotension and $9(90.0 \%)$ experienced no orthostatic hypotension. Furthermore, out of 3 respondents (100\%) using typical antipsychotics, 1 (33.3\%) experienced orthostatic hypotension, while 2 respondents $(66.7 \%)$ experienced none.

The above information shows that the results of the first study did not have a significant positive effect between the use of antipsychotics on orthostatic hypotension in schizophrenic patients. This was due to drug reactions that cause more potential side effects. Furthermore, the use of antipsychotic drugs for a long period of time causes more visible effect of physiological function

Table 1. The use of antipsychotics in schizophrenic patients.

\begin{tabular}{lcc} 
Antipsychotic drug & Frequency & Percentage \\
Combination & 40 & $75.47 \%$ \\
Atypical & 10 & $18.87 \%$ \\
\hline Typical & 3 & $5.66 \%$ \\
\hline
\end{tabular}

Table 2. The incidence of orthostatic hypotension in schizophrenic patients.

\begin{tabular}{lcc} 
& Frequency & Percentage \\
Orthostatic hypotension & 5 & $9.43 \%$ \\
No orthostatic hypotension & 48 & $90.57 \%$ \\
\hline
\end{tabular}

Table 3. The fall risk in schizophrenic patients

\begin{tabular}{lcc} 
Falling risk scale & Frequency & Percentage \\
High $\geq 90$ & 0 & $0 \%$ \\
Medium $51-90$ & 53 & $100 \%$ \\
\hline Low $\leq 50$ & 0 & $0 \%$ \\
\hline
\end{tabular}

Table 4. The effect of antipsychotics' use on orthostatic hypotension in schizophrenic patients.

\begin{tabular}{lccccccc} 
Use of antipsychotics & $\begin{array}{c}\text { Orthostatic } \\
\text { hypotension }\end{array}$ & $\begin{array}{c}\text { No orthostatic } \\
\text { hypotension }\end{array}$ & & Total & P-value \\
Combination & 3 & $7.5 \%$ & 37 & $92.5 \%$ & 40 & $100 \%$ & 0.335 \\
Atypical & 1 & $10.0 \%$ & 9 & $90.0 \%$ & 10 & $100 \%$ & 0.199 \\
Typical & 1 & $33.3 \%$ & 2 & $66.7 \%$ & 3 & $100 \%$ & \\
\hline
\end{tabular}

Table 5. The effect of orthostatic hypotension on the risk of falls in schizophrenic patients

\begin{tabular}{|c|c|c|c|c|c|c|c|c|c|c|}
\hline \multirow{2}{*}{$\begin{array}{l}\text { Categories } \\
\text { Orthostatic hypotension }\end{array}$} & & & nsc & $\begin{array}{l}\text { I Risk } \\
\text { Im } \\
\text { 0) }\end{array}$ & & & \multicolumn{2}{|c|}{ Total } & p-value & $\mathbf{r}$ \\
\hline & 0 & $0 \%$ & 5 & $100 \%$ & 0 & $0 \%$ & 5 & $100 \%$ & 0.000 & 0.483 \\
\hline No orthostatic hypotension & 0 & $0 \%$ & 48 & $100 \%$ & 0 & $0 \%$ & 48 & $100 \%$ & & \\
\hline
\end{tabular}


symptoms in schizophrenic patients

Based on Table 5, the results of the statistical tests using the Spearman rank correlation analysis obtained a p-value of 0.000 $(\mathrm{p}<0.001)$, and a value of $\mathrm{r}=0.483$ at the level of correlation coefficient in the medium category. This means that there is a significant positive effect between orthostatic hypotension and the risk of falling in schizophrenic patients. The results showed that the 5 respondents had orthostatic hypotension and the remaining 48 without it, were all included in the moderate score category (5190). Furthermore, the results of the second study found that there was a significant positive effect between orthostatic hypotension on the risk of falls in schizophrenic patients. This is because orthostatic hypotension acts as a supporting factor for the occurrence of unwanted events such as the risk of falls among patients. Therefore, Edmonson's scale has been developed as a specialized risk of falling assessment tool used in psychiatric units to target additional risk factors specifically for patients with mental illness. ${ }^{15,16}$ Management of schizophrenia with psychopharmaceuticals is a long-term treatment, and an example is the use of antipsychotic drugs. ${ }^{9-11}$ This drug causes side effects such as orthostatic hypotension, ${ }^{12}$ which is a contributing factor to the occurrence of unwanted events. In a previous study on the use of antipsychotics and its side effects in schizophrenic patients at RSJ Sambang Lihum South Kalimantan in February 2016, the statistical results from the analysis showed that antipsychotic combination therapy and haloperidol-clozapine $(26.06 \%)$ is the most widely used therapy $(90.6 \%)$ and drug. ${ }^{17}$ The results above correspond with the results of this study, especially in the combined administration of the most commonly used typical and atypical antipsychotics such as haloperidol - clozapine, chlorpromazine - olanzapine and risperidone - clozapine. This is because the medications used have side effects on the cardiovascular system, such as orthostatic hypotension. ${ }^{18,19}$

According to Stroup and Gray, all antipsychotics carry a risk of orthostatic hypotension which is defined as a decrease in systolic blood pressure $\geq 20 \mathrm{mmHg}$ or a decrease in diastolic blood pressure $\geq 10 \mathrm{mmHg}$ within three minutes of post-standing. ${ }^{20}$ Therefore, there was an correlation between medication independently of an increased risk of falling. ${ }^{21-23}$ It is because adverse drug reactions that are as unwanted effects of drug treatment, ${ }^{24}$ with adrenergic receptors. ${ }^{25}$ Furthermore, more on the dose of antipsychotic drugs or due to other physical conditions, tend to developed orthostatic hypotension. Prevention of orthostatic hypotension depends on the use of antipsychotics, ${ }^{23,26}$ stepwise titration and doses distributed throughout the day (to minimize peak levels). The statistical results of the bivariate analysis of the first study using the contingency coefficient correlation obtained a value of 0.199 with a p-value of 0.335 (alpha value $>0.05$ ) This means that there is no significant positive effect between the use of antipsychotics on orthostatic hypotension in schizophrenic patients. The statistical results of the bivariate analysis of the second study using the Spearman Rank obtained a p-value of $0.000(p<0.001)$ and the level of the correlation coefficient was in the moderate category with a value of $r=0.483$. In a previous survey, ${ }^{27}$ diastolic measurement was significant for the risk of falling within 2 min after the change in position. ${ }^{27}$ The implications of this study include the use of antipsychotics. Therefore, room nurses need to monitor and maintain the patient's condition while in treatment in collaboration with a team of doctors that treats and pay special attention to the type of drug used, dosage, amount, frequency and duration. This is because each antipsychotic drug has different side effects, and one of which is a problem in the cardiovascular system such as orthostatic hypotension. In orthostatic hypotension, it is important to observe the patient's condition with other side effects that occur such as excessive rest and lack of movement of the body. Furthermore, it also includes special monitoring by nurses such as helping the patients to rest during the events of symptomatic effects accompanied by orthostatic hypotension. Nurses could collaborate with other medical personnel on medications to minimize the effects of the symptoms and to increase blood pressure. Additionally, nurses could help patients in doing exercise or active range of motion (ROM) to improve their level of mobilization in order to prevent the risk of falls.

\section{Conclusions}

The results of the study showed that there was no significant positive effect between the use of antipsychotics on orthostatic hypotension in schizophrenic patients. It had a correlation value and a contingency coefficient of 0.199 with a p-value of 0.335 (alpha value $>0.05$ ). On the other hand, there was a significant positive effect between orthostatic hypotension on the risk of falls in schizophrenic patients with a p-value of $0.000(\mathrm{p}<0.001)$ and a moderate category correlation coefficient with a value of $r=0.483$. There are suggestions that are useful for the development of the results of this study, such as the need for further research in overcoming the incidence of orthostatic hypotension as an effort to prevent or reduce the risk of falls in schizophrenic patients.

Correspondence: Sari Narulita, Mental Health Nursing Department, Binawan University, Jakarta, Indonesia. Jln. Kalibata Raya No. 25-30, Jakarta Timur 13630, Indonesia.

Tel. +62.21 .80880882 - Fax: +62.21 .80880883$.

E-mail: sari@binawan.ac.id

Acknowledgment: The authors express their gratitude to God, their parents, brothers, uncle, lecturers and all committee of 1 st INHSS for their kind support and encouragements during this study.

Key words: Antipsychotics drugs; orthostatic hypotension; fall risk

Contributions: All authors contributed equally to this article. Furthermore, this study was conducted by F, while SN, YH served as lecturers and supervisors and reviewed the final article.

Conflict of interests: The author declares no potential conflict of interest.

Funding: This study was financially supported by personal fees.

Ethical Approval: This study has been approved by the health research ethics committee of the Binawan University Jakarta and Dr. H. Marzoeki Mahdi Hospital Bogor.

Conference presentation: Part of this study was presented at the $1^{\text {st }}$ International Nursing and Health Sciences Symposium, November $13^{\text {th }}$ to $15^{\text {th }} 2020$, Brawijaya University, Malang, Indonesia.

Received for publication: 17 January 2021.

Accepted for publication: 25 March 2021.

oCopyright: the Author(s), 2021

Licensee PAGEPress, Italy

Journal of Public Health Research 2021;10:2184

doi:10.4081/jphr.2021.2184

This work is licensed under a Creative Commons Attribution NonCommercial 4.0 License (CC BY-NC 4.0). 


\section{References}

1. Stuart GW. Principles and practice of psychiatric nursing. Singapore: Elsevier; 2016.

2. Stuart GW, Keliat BA, Pasaribu J. [Prinsip dan Praktik Keperawatan Kesehatan Jiwa Stuart (Stuart's Mental health nursing principles and practices)]. Vol. 1 \& 2. [Indonesian Translation]. Singapore: Elsevier; 2016.

3. Adianta IKA, Putra IMS. [Hubungan dukungan keluarga dengan tingkat kepatuhan minum obat pada pasien skizofrenia (The relationship between family support and the level of medication adherence in schizophrenic patients)].[Article in Indonesian]. J Ris Kesehat Nas 2017;1:1-7.

4. Sadock BJ, Sadock VA, Ruiz P. Kaplan \& Sadock's compherensive textbook of psychiatry. Philadelphia: Lippincott Williams Wolters Kluwer; 2017.

5. WHO. Global report on falls prevention in older age. Geneva: World Health Organization; 2007. Available from: https://apps.who.int/iris/handle/10665/43811

6. Maramis A, Van Tuan N, Minas H. Mental health in southeast Asia. Lancet 2011;377:700-2.

7. Royal College of Psychiatrists. Report of the National Audit of Schizophrenia (NAS) 2012. London: Healthcare Quality Improvement Partnership; 2012.

8. Kemenkes R. [Hasil Data Penelitian Riskesdas Litbang Depkes RI: Angka Kejadian Skizofrenia di Indonesia (Results of Research Data, Ministry of Health Research and Development: Incidence of schizophrenia in Indonesia)].[Book in Indonesian]. Jakarta: Kemenkes RI; 2018.

9. Yulianty M, Cahaya N, Srikartika VM. [Studi penggunaan antipsikotik dan efek samping pada pasien skizofrenia di Rumah Sakit Jiwa Sambang Lihum Kalimantan Selatan (Study of the use of antipsychotics and side effects in schizophrenic patients at Sambang Lihum Mental Hospital, South Kalimantan)].[Article in Indonesian]. J Sains Farm dan Klin 2017;3:153-64.

10. Neal MJ. Medical pharmacology at a glance. Oxford: Willey Blackwell; 2016.

11. Gardner DM, Baldessarini RJ, Waraich P. Modern antipsychotic drugs: a critical overview. J C Coll Psychiatr 2018;172:1703-11.

12. Varcarolis E. Foundations of psychiatric mental health nursing. Philadelphia: Saunders; 2018.

13. Lieberman JA, Richard SEK, Susan GS, et al. The effects of atypical antipsychotic drugs on neurocognitive impairment in schizophrenia: a review and meta analysis. Schizophr Bull 2014;25:201-22.
14. Magkas N, Tsioufis C, Thomopoulos C, et al. Orthostatic hypotension: from pathophysiology to clinical applications and therapeutic considerations. J Rev Pap 2019;21:546-54.

15. Wynaden D, Heslop B, Heslop K, et al. The chasm of care: Where does the mental health nursing responsibility lie for the physical health care of people with severe mental illness? Int J Ment Health Nurs 2016;25:516-25.

16. Dyke DV, Singley B, Speroni KG, et al. Evaluation of fall risk assessment tools for psychiatric patient fall prevention: a comparative study. J Psychosoc Nurs Ment Health Serv 2014;52:30-5.

17. Rahaya A, Cahaya N. [Studi retrospektif penggunaan trihexyfenidil pada pasien skizofrenia rawat inap yang mendapat terapi antipsikotik di Rumah Sakit Jiwa Sambang Lihum (Retrospective study of the use of trihexyphenidil in inpatients of schizophrenia receiving antipsychotic therapy at the Sambang Lihum Mental Hospital)].[Article in Indonesian]. Galen J Pharm 2016;2:124-131.

18. Leung JY, Barr AM, Procyshyn RM, et al. Cardiovascular sideeffects of antipsychotic drugs: the role of the autonomic nervous system. Pharmacol Ther 2012;135:113-22.

19. Milazzo V, Stefano CD, Servo S, et al. Drugs and orthostatic hypotension: evidence from literature. J Hypertens Open Access 2012;1:1-8.

20. Stroup TS, Gray N. Management of common adverse effects of antipsychotic medications. Clin Update 2018;17:341-56.

21. Zia A, Kamaruzzaman SB, Tan MP. The consumption of two or more fall risk-increasing drugs rather than polypharmacy is associated with falls. Orig Artic Epidemiol Clin Pract Heal 2016;1:1-8.

22. Australian Institute of Health and Welfare. Mental health services-in brief 2017. Cat. no. HSE 192. Canberra: AIHW; 2017.

23. Edmonson D, Wilson S. Development of the Edmonson psychiatric fall risk assessment tool. J Psychosoc Nurs 2014;49:25-30.

24. Bangwal R, Bisht S, Saklani S, et al. Psychotic disorders, definition, sign and symptoms, antipsychotic drugs, mechanism of action, pharmacokinetics \& pharmacodynamics with side effects \& adverse drug reactions: Updated systematic review article. J Drug Deliv Ther 2020;10:163-72.

25. Lin Y-S, Ho P-S, Liang C-S. Severe orthostatic hypotension after adding low-dose aripiprazole to clozapine. Arch Clin Psychiatry (São Paulo) 2017;44:84.

26. Abraham S. Looking for a psychiatric fall risk assessment tool. Ann Psychiatry Ment Health 2016;4:1061.

27. Juraschek SP, Daya N, Appel LJ, et al. Orthostatic hypotension in middle-age and risk of falls. Am J Hypertens 2017;30:18895. 